\title{
SMPD4 wt Allele
}

National Cancer Institute

\section{Source}

National Cancer Institute. SMPD4 wt Allele. NCI Thesaurus. Code C105036.

Human SMPD4 wild-type allele is located in the vicinity of 2q21.1 and is approximately 31 $\mathrm{kb}$ in length. This allele, which encodes sphing omyelin phosphodiesterase 4 protein, plays a role in phospholipid metabolism. 